\title{
Green Infrastructure Can Improve the Lives of Slum Dwellers in African Cities
}

\author{
Olumuyiwa Bayode Adegun* \\ Department of Architecture, Federal University of Technology, Akure, Nigeria
}

Slums and informal settlements in African cities are notably connected to green spaces and natural ecosystems serving as green infrastructure. Green Infrastructure holds the potential for improvement of the quality of life and the environment by harnessing benefits for people's livelihoods, food security, environmental regulation, socio-cultural appropriation, etc., and by addressing constraints to greening. Policy initiatives and relevant greening programs, especially those utilizing participatory, low-cost, socio-economically empowering approaches, are recommended.

Keywords: green infrastructure, slum upgrading, ecological infrastructure, ecosystem services, urban sustainability

\section{OPEN ACCESS}

Edited by:

Kumelachew Yeshitela Habtemariam, Addis Ababa University, Ethiopia

Reviewed by:

Danielle Sinnett,

University of the West of England,

United Kingdom

Simon Bell,

University of Edinburgh,

United Kingdom

${ }^{*}$ Correspondence:

Olumuyiwa Bayode Adegun obadegun@futa.edu.ng

Specialty section:

This article was submitted to Urban Greening,

a section of the journal

Frontiers in Sustainable Cities

Received: 24 October 2020 Accepted: 27 January 2021

Published: 05 March 2021

Citation:

Adegun OB (2021) Green

Infrastructure Can Improve the Lives of Slum Dwellers in African Cities. Front. Sustain. Cities 3:621051. doi: 10.3389/frsc.2021.621051

\section{INTRODUCTION}

Low-income households in African cities usually live in slums and informal settlements located in areas that are environmentally sensitive, ecologically significant, and/or biodiversity-rich, e.g., near streams, on low-lying riverbanks, within wetlands, on steep hillsides, servitudes, buffer strips, and other kinds of interstitial space. Some forms of urban agricultural practices are notable within these areas. The United Nations' estimate shows that over 238 million people currently live in areas regarded as slums or informal settlements within cities in sub-Saharan Africa (United Nations Human Settlements Programme., 2016).

Urban Green Infrastructure covers strategically planned networks of natural landforms and green spaces as well as an "informal network of micro-activity to supplement the strategic-level interventions," including agri-food landscapes (Jerome, 2017). Both deliver diverse goods and services that support human sustenance. People living in slums and informal settlements relate to green spaces and natural ecosystems that can function beneficially as green infrastructure in different ways (Adegun, 2017a; Douglas, 2018; Birtchnell et al., 2019; Diep et al., 2019). This relationship holds the key to improvements not only in environmental quality, but also in quality of life for low-income residents.

Interventions within slums and informal communities in African cities tend to impact the residents' relationship with green infrastructure. It is imperative to harness the potential benefits in order to improve the gains, while also addressing any possible ensuing pain. Policy initiatives have a critical role in this regard.

This policy brief relies on evidence emanating from recent research (Adegun, 2016, 2018a, 2019) to show important areas for policy and program actions at the municipal level and for stakeholders in the third sector. The research is based on case studies in 3 areas within Johannesburg, whose situations are similar to other cities in sub-Saharan Africa. The first area, Kya Sands, is an informal settlement that has not experienced any form of substantive formal improvements. The second, Ruimsig, has been partially re-blocked-dwellings realigned to allow for services and infrastructure. The third, Cosmo City, is a greenfield development where households from informal settlements were relocated. Semi-structured interviews, 
transect walks, focus group discussions, and a survey were utilized for data collection across the 3 areas. These were supplemented by in-depth interviews with purposively selected key informants. The brief also draws on related work within low-income communities in Lagos (Akinwolemiwa et al., 2018; Adegun, 2020).

\section{RESULTS}

\section{Benefits of Green Infrastructure in Low-Income Informal Communities Are Highlighted Through the Following}

(i) Domestic gardens serve as a source of food (contributing to household nutrition and food security), herbs (medicine), and modest monetary gains from the sale of garden produce (augmenting household income).

(ii) Communal gardens provide means of social interaction, thus enhancing social capital: the appropriation of open communal green spaces and garden products for religious activities and community engagements deliver socio-cultural benefits.

(iii) Flood regulation and local climate moderation, including wind and temperature control, were reported by residents. Experimentation with Vertical Greening Systems within a lowincome community in Lagos shows the possibility of reducing indoor air temperature by up to $2.3^{\circ} \mathrm{C}$ across wet and dry seasons (Akinwolemiwa et al., 2018).

(iv) Natural ecosystems complement available but inadequate basic services and serve as a quasi-amenity. For instance, riparian spaces support recreational activities in the absence of formal parks (See Figure 1). The stream provides water, making up for shortfalls in potable water supply from communal taps. In the absence of electricity connections, firewood used for fuel is harvested from trees within and around communities.

(v) Aesthetics: beautifying the home and its immediate environment through different plants.

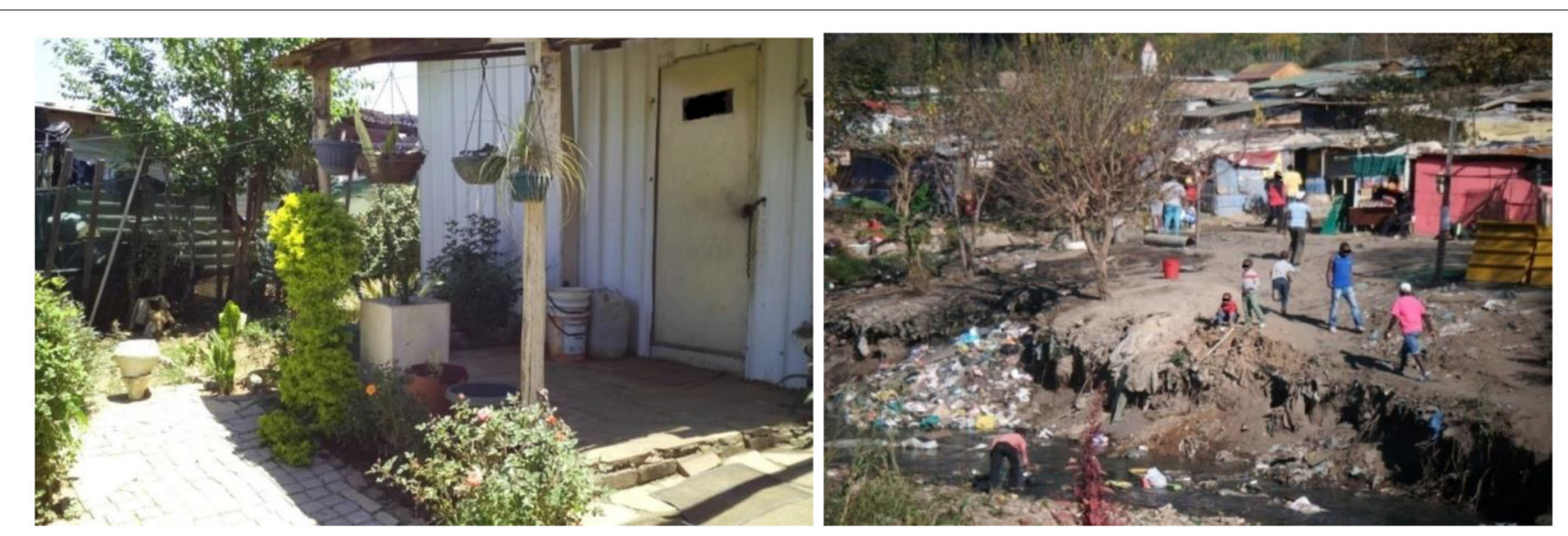

FIGURE 1 | Greening at the household (left) and Riparian space utilization for recreation within informal settlements. Source: Author's Photo, taken in 2015.
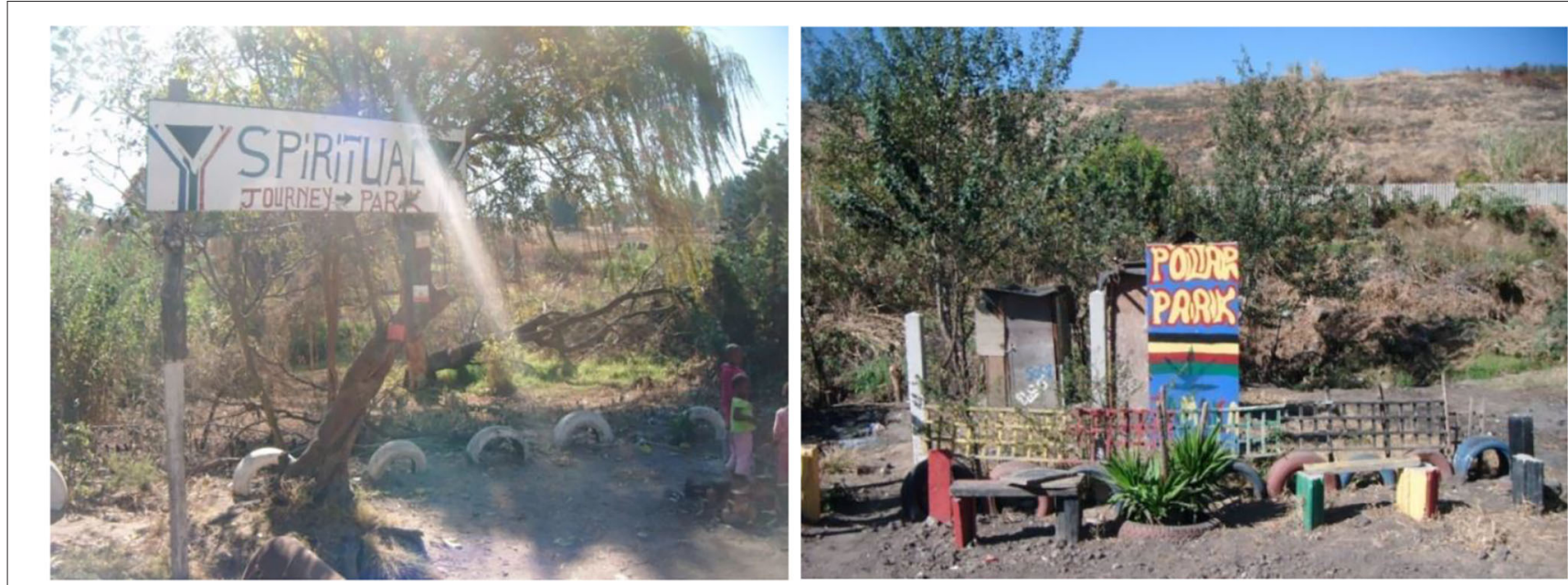

FIGURE 2 | Self-built parks within a settlement in Johannesburg. Source: Author's Photo, taken in 2014. 


\section{Constraints to Greening in Informal Settlements}

(i) Insecure tenure in informal settlements manifests itself through lack of proper title to land, eviction threats, high percentage of renters, and concentration of migrants. These often discourage substantive long-term investment in gardens and other forms of green spaces.

(ii) Space limitations: Many households recognize small plot size as a hinderance to domestic gardening. Increasing pressure on limited land available for housing may not guarantee increased plot size in future.

(iii) Soil conditions: Some communities have contaminated soil (from dumping and sewerage disposal), saline soil (for coastal areas), or already compacted soil. These do not ordinarily support vegetation growth.

(iv) Socio-economic struggles: Poor households' considerations for income generation tend to override interests in greening their dwellings. An example is preference for rentable backrooms to well-kept productive home gardens.

\section{Approach to Green Infrastructure Development}

Informal areas are often not included in municipal plans and development of amenities including green spaces such as parks. This situation excludes the residents from benefiting from the positive externalities of green infrastructure. In response, makeshift parks self-built from recycled materials are a notable feature within some settlements. See examples in Figure 2.

The approach taken for the development of green infrastructure must be reconsidered. There is evidence of residents' willingness to pay for green infrastructure, namely communal gardens (allotment), riparian corridor rehabilitation and maintenance, a community park, and children's park (Adegun, 2017b). Table 1 shows the response across a range of

TABLE 1 | Kya Sands Settlement residents' willingness to pay for green space development.

\begin{tabular}{|c|c|c|c|}
\hline & Entrepreneurial resident & NGO & Government \\
\hline Yes (Willing to pay) & $83.51 \%$ & $73.93 \%$ & $42.02 \%$ \\
\hline No (Not willing to pay) & $16.48 \%$ & $26.06 \%$ & $57.98 \%$ \\
\hline
\end{tabular}

Source: Field survey, 2014.

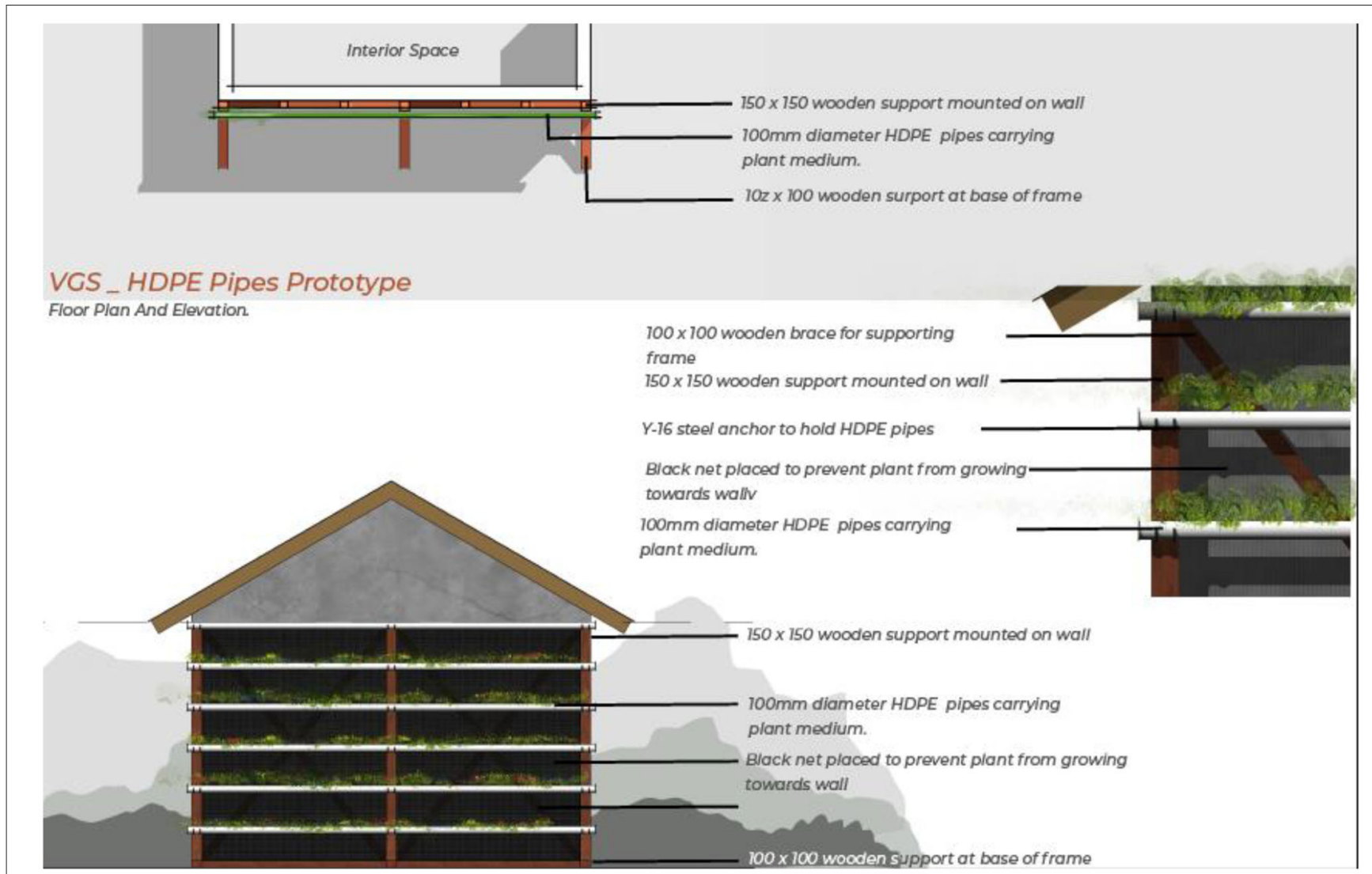

FIGURE 3 | Low-cost vertical farm suitable for low-income environments. Source: Designed by Climate Research for Development (CR4D) Project Team, Federal University of Technology, Akure, Nigeria. 
possible developers. There is lack of willingness to pay for spaces developed by governments compared with those of residents and NGOs. This level of willingness shows that non-state actors must be engaged to contribute to green infrastructure development.

In-situ upgrading of informal settlements creates opportunities for development of community-scale green infrastructure. An example in Johannesburg (Ruimsig settlement) reflects opportunities that come with these kinds of intervention (Adegun, 2018b). In-situ upgrading, more than relocation to far-flung new housing, is a better approach at addressing the bundle of sustainability considerations (environmental, social, and economic) for households in informal settlements.

\section{POLICY IMPLICATIONS}

- Strengthening urban greening considerations within national policies that guide housing development, slum upgrading, and management of informal settlements.

- Including slums and informal settlements within municipal budgetary allocations for green amenity development.

- Creating framework(s) for the participation of non-state actors in development of green infrastructure within informal, lowincome urban communities.

- Slum upgrading programs must incorporate the development of natural ecosystems for green infrastructure. Ecological infrastructure must be utilized as a route to catalytic incremental upgrading.

- Design and management of urban green infrastructure must incorporate residents in informal communities so that their views and values are duly incorporated.

\section{REFERENCES}

Adegun, O. B. (2016). Informal settlement intervention and green infastructure: exploring just sustainability in Kya Sands, Ruimsig and Cosmo City in Johannesburg (Unpublished Ph.D. thesis), University of the Witwatersrand, Johannesburg.

Adegun, O. B. (2017a). Green infrastructure in relation to informal urban settlements. J. Archit. Urban. 41, 22-33. doi: 10.3846/20297955.2017.1296791

Adegun, O. B. (2017b). Developing green infrastructure in a johannesburg informal settlement: investigating residents' willingness to pay. Proc. Eng. 198, 176-186. doi: 10.1016/j.proeng.2017.07.081

Adegun, O. B. (2018a). Residents' relationship with green infrastructure in Cosmo City, Johannesburg. J. Urban. Int. Res. Placemak. Urban Sust. 11, 329-346. doi: 10.1080/17549175.2018.1470103

Adegun, O. B. (2018b). Exploring just sustainability in re-blocking intervention in a johannesburg informal settlement. J. Asian Afr. Stud. 53, 782-796. doi: 10.1177/0021909617725771

Adegun, O. B. (2019). Green infrastructure in informal unplanned settlements: the case of Kya Sands, Johannesburg. Int. J. Urban Sust. Dev. 11, 68-80. doi: 10.1080/19463138.2019.1565412

Adegun, O. B. (2020). Adapting to Climate Challenges in Low-Income Coastal Settlements in Nigeria. Johannesburg: Faces of the City Seminar, University of the Witwatersrand. doi: 10.3390/urbansci4030033

Akinwolemiwa, O. H., de Souza, C. B., De Luca, L. M., and Gwilliam, J. (2018). Building community-driven vertical greening systems for peopl living on less than£ 1 a day: a case study in Nigeria. Build. Environ. 131, 277-287. doi: 10.1016/j.buildenv.2018.01.022

\section{ACTIONABLE RECOMMENDATIONS}

- Introducing, at the municipal/sub-municipal levels, urban greening initiatives directed at low-income households and communities. Such greening programs should be linked to people's livelihoods and economic upliftment.

- Improving awareness of benefits from green infrastructure among slum dwellers.

- Incentives that encourage households to initiate and sustain greening activities and pro-environmental behavior.

- Adopting and promoting vertical farming techniques that utilize little or no (land) space. This addresses increasing density and can be low-cost and do-it-yourself in nature. An adaptable prototype is shown in Figure 3.

\section{AUTHOR CONTRIBUTIONS}

OA conceived, conducted, analyzed, and reported the study.

\section{FUNDING}

This work was partly supported through the Climate Research for Development (CR4D) Postdoctoral Fellowship (CR4D19-03) implemented by the African Academy of Sciences (AAS) in partnership with the United Kingdom's Department for International Development (DfID) Weather and Climate Information Services for Africa (WISER) program and the African Climate Policy Center (ACPC) of the United Nations Economic Commission for Africa (UNECA). Statements made and views expressed in this work are solely the responsibility of the authors.

Birtchnell, T., Gill, N., and Sultana, R. (2019). Sleeper cells for urban green infrastructure: Harnessing latent competence in greening dhaka's slums. Urban Forest. Urban Green. 40, 93-104. doi: 10.1016/j.ufug.2018.0 5.014

Diep, L., Dodman, D., and Parikh, P. (2019). Green infrastructure in informal settlements through a multiple level perspective. Water Alternat. 12, 554-570.

Douglas, I. (2018). The challenge of urban poverty for the use of green infrastructure on floodplains and wetlands to reduce flood impacts in intertropical Africa. Landscape and Urban Planning, 180, pp.262-272.; doi: 10.1016/j.landurbplan.2016.0 9.025

Jerome, G. (2017). Defining community-scale green infrastructure. Landsc. Res. 42, 223-229. doi: 10.1080/01426397.2016.1229463

United Nations Human Settlements Programme. (2016). World Cities Report 2016-Urbanization and Development-Emerging Features. Nairobi: UNHabitat. doi: 10.18356/d201a997-en

Conflict of Interest: The author declares that the research was conducted in the absence of any commercial or financial relationships that could be construed as a potential conflict of interest.

Copyright (C) 2021 Adegun. This is an open-access article distributed under the terms of the Creative Commons Attribution License (CC BY). The use, distribution or reproduction in other forums is permitted, provided the original author(s) and the copyright owner(s) are credited and that the original publication in this journal is cited, in accordance with accepted academic practice. No use, distribution or reproduction is permitted which does not comply with these terms. 